Mongolian Academy of Sciences
Mongolian Journal of Chemistry
Institute of Chemistry \& Chemical Technology

\title{
Adsorption kinetics for the removal of copper(II) from aqueous solution by adsorbent PSTM-3T
}

\author{
G.Burmaa $^{1}$, O.Nasantogtokh ${ }^{1}$, N.Narantsogt ${ }^{2}$, A.Perlee-Oidov ${ }^{1}$ \\ ${ }^{1}$ Institut of Chemistry and Chemical Technology, MAS, Ulaanbaatar-13330 \\ ${ }^{2}$ Mongolian State University of Education, School of Natural Sciences
}

\begin{abstract}
The batch removal of copper (II) from aqueous solution under different experimental conditions using silicon-organic sorbent poly[N,N'-bis(3-silseskquioxanilpropyl)thiocarbamide] (PSTM-3T) was investigated in this study. This sorbent was produced from the hydrolytic polycondensation reaction. The removal was favoured at $\mathrm{pH}=5$ for PSTM-3T. The effects of concentration and temperature have been reported. PSTM-3T was found to efficiently remove $\mathrm{Cu}$ (II) from solution. The batch sorption kinetics have been tested for a first-order reaction. The rate constants of adsorption have been calculated. The thermodynamic parameters $\left(\Delta \mathrm{G}^{0}, \mathrm{~K}_{\mathrm{c}}\right)$ obtained to indicate the endothermic nature of $\mathrm{Cu}(\mathrm{II})$ adsorption on PSTM-3T.
\end{abstract}

Keywords: Poly[N,N'-bis(3-silseskquioxanil)thiocarbamide], Langmuir, Freundlich isotherm, Thermodynamic parameters

\section{Introduction}

dsorption processes for water
treatment have had a long and
productive history. Activated carbon has been widely used in wastewater treatment to remove organic and inorganic pollutants. It was also found that activated carbon has a great potential to remove heavy metals such as cadmium, chromium, lead and copper according to the reference [1].

Heavy metals are widely used in modern industries, including textile, leather, tanning, electroplating and metal finishing. They are released to environment either in treated wastewater to surface waters or as sludge applied to landfill. Copper is known to be a toxic metal. Because of its toxicity, it is imperative to significantly reduce its discharge levels [2].

The pre-concentration and separation of elements by use of chelating silicon organic
[3-6] polymers have been reported. However, most of chelating silicon organic polymers are used for pre-concentration and determination of noble metal ions, the synthesis of silicon organic polymers usually takes a long time and the synthetic process is complicated.

Previously, we studied the removal of $\mathrm{Cr}(\mathrm{VI})$ from wastewater, using PSTM-3T and activated carbon produced from sawdust under selected conditions [7]. These were preliminary studies. In this research, we investigate the adsorption kinetics of PSTM3T under wide range of conditions.

\section{Experimental}

\section{Materials characterization}

Silicon-organic polymer

$$
\begin{gathered}
{\left[-\mathrm{O}_{1.5} \mathrm{Si}\left(\mathrm{CH}_{2}\right)_{3} \mathrm{HNC}(\mathrm{S}) \mathrm{NH}\left(\mathrm{CH}_{2}\right)_{3} \mathrm{SiO}_{1.5^{-}}\right]_{\mathrm{n}}-} \\
\text { poly[N,N'-bis }(3-
\end{gathered}
$$

silseskquioxanilpropyl)thiocarbamide] used in this study was synthesized [3] in Russia. 
The adsorbent used in this work were characterized by scanning electron microscope (SEM) (Fig. 1). This figure shows that the PSTM-3T has an irregular and porous surface, which indicates high surface areas. Moreover, the surface area of PSTM-3T is $490 \mathrm{~m}^{2} / \mathrm{g}$ and the total pore volume is 3.53 $\mathrm{ml} / \mathrm{g}$.

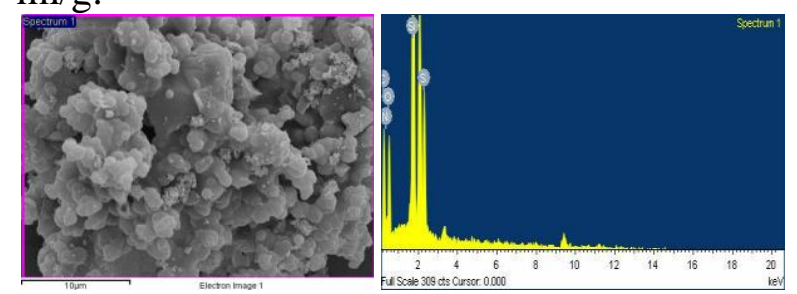

Fig. 1. SEM/EDS image of PSTM-3T

Energy dispersive spectrometer (EDS) was also used to analyze sorbent PSTM-3T. The EDS analyses provided a rudimentary and after adsorbed copper compositions for the PSTM-3T. The compositions from the peak areas (Fig.1) are calculated as shown in Table 1.

Table 1. EDS composition of PSTM-3T

\begin{tabular}{|c|c|c|}
\hline Element & Weight (\%) & Atomic, $(\%)$ \\
\hline Silica (Si) & 18.40 & 10.20 \\
\hline Carbon (C) & 36.94 & 47.90 \\
\hline Oxygen (O) & 23.16 & 22.54 \\
\hline Sulfur (S) & 7.27 & 3.53 \\
\hline $\operatorname{Nitrogen}(\mathrm{N})$ & 14.23 & 15.83 \\
\hline
\end{tabular}

\section{Adsorption}

The measurement of adsorption kinetics of the PSTM-3T was carried out by shaking $0.05 \mathrm{~g}$ of PSTM-3T with $50 \mathrm{ml}$ of $\mathrm{Cu}$ (II) solution of known concentration in $100 \mathrm{ml}$ conical flask placed in a stirrer/hot plate (Corning PC-620D) provided with a temperature controller. The removal kinetics of the $\mathrm{Cu}$ (II) was investigated by drawing samples after the desired contact time and the filtrate was analyzed for the remaining $\mathrm{Cu}$ (II) concentration. A spectrophotometer (HITACHI, U-1000) was employed at a wavelength of $430 \mathrm{~nm}$ with sodium diethyl dithiocarbamate reagent to determine the remaining concentrations of $\mathrm{Cu}(\mathrm{II})$ in each sample solutions after adsorption at the desired time intervals. The analysis was carried out according to the procedure given by the reference [8]. The same procedure has been used to study the effect of initial concentration, $\mathrm{pH}$ and temperature. The $\mathrm{pH}$ was adjusted with either $0.1 \mathrm{M} \mathrm{HCI}$ or $0.1 \mathrm{M}$ $\mathrm{NaOH}$ as required.

The equilibrium isotherm was determined by mixing $0.05 \mathrm{~g}$ of PSTM-3T with $50 \mathrm{ml}$ of copper solution in $100 \mathrm{ml}$ conical flask at the required temperature. Each isotherm consisted of nine copper concentrations varied from 1000 to $10000 \mathrm{ppm}$. The flasks containing copper solution and PSTM-3T were placed in a shaker and agitated for 40 min at the required temperature and at a fixed agitation speed of $500 \mathrm{rpm}$. The equilibrium concentrations were measured by the spectrophotometer and referenced with the calibration curve. The equilibrium adsorption capacity was calculated using the equation: $\mathrm{q}_{\mathrm{e}}=\left(\mathrm{C}_{0}-\mathrm{C}\right) \mathrm{V} / \mathrm{M}$ (1) where $\mathrm{q}_{\mathrm{e}}(\mathrm{mg} / \mathrm{g})$ is the equilibrium adsorption capacity, $\mathrm{C}_{0}$ and $\mathrm{C}$ are the initial and equilibrium concentration $(\mathrm{mg} / \mathrm{l})$ of $\mathrm{Cu}(\mathrm{II})$ ions in solution, $\mathrm{V}(\mathrm{l})$ is the volume and $\mathrm{M}(\mathrm{g})$ is the weight of sorbent.

The accuracy of temperature and concentration measurements was $\pm 0.5^{\circ} \mathrm{C}$ and \pm 0.02 ppm, respectively.

\section{Results and Discussions Effect of $p H$}

The adsorption of $\mathrm{Cu}(\mathrm{II})$ by PSTM-3T at different $\mathrm{pHs}$ at an initial concentration of 20 $\mathrm{mg} / \mathrm{l}$ and a temperature of $90^{\circ} \mathrm{C}$ is shown in Fig. 2. For PSTM-3T, particle size was 0.2 $\mathrm{mm}$. For PSTM-3T, the amount adsorbed increases from 2.0 to $7.0 \mathrm{mg} / \mathrm{g}$ as the $\mathrm{pH}$ decreases from 5 to 2 . This indicates that the adsorption capacity of the adsorbent is clearly $\mathrm{pH}$ dependent. It is obvious that $\mathrm{pH}$ determines the extent of the $\mathrm{Cu}$ (II) removal as well as providing a favourable adsorbent surface charge for the adsorption to occur.

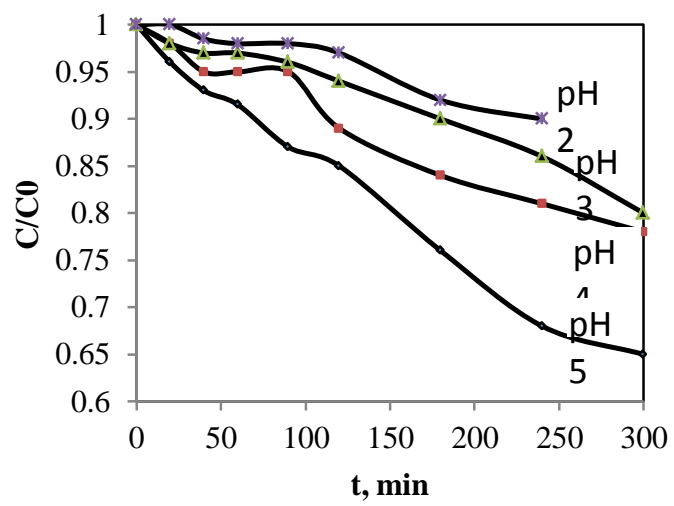

Fig.2. Time variation of $\mathrm{Cu}(\mathrm{II})$ adsorption on PSTM$3 \mathrm{~T}$ at different $\mathrm{pHs}$. 


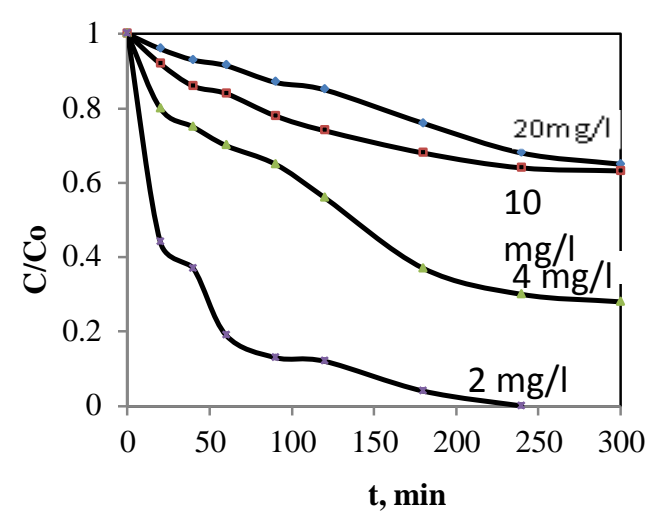

Fig.3. Time variation of $\mathrm{Cu}(\mathrm{II})$ adsorption on PSTM-3T at different initial concentrations.

$\mathrm{Cu}$ (II) exists in different forms in aqueous solution and the stability of these forms is dependent on the $\mathrm{pH}$ of the system. A characteristic of the sorption of heavy metal ions onto the surface is that at a set bulk solution heavy metal concentration the sorption is greatest at a $\mathrm{pH}$ value that is just slightly more acidic than the $\mathrm{pH}$ at which there is bulk precipitation of the metal hydroxide. As $\mathrm{pH}$ is further raised, once the bulk solubility limit is reached, the sorption is greatly reduced because the metal ion is removed from solution by the bulk precipitation. The relative concentration of $\mathrm{Cu}$ (II) species in system containing $1 \times 10^{-4}$ $\mathrm{mol} / \mathrm{l} \mathrm{Cu}(\mathrm{II})$ [2] is shown in Fig.4. This figure clearly shows $\mathrm{Cu}(\mathrm{II})$ species distribution for a total $\mathrm{Cu}(\mathrm{II})$ concentration of $1 \times 10^{-4} \mathrm{~mol} / \mathrm{l}$. It is noted that maximum sorption of $\mathrm{Cu}$ (II) occurs at a $\mathrm{pH}$ value slightly more acidic than the $\mathrm{pH}$ of bulk precipitation of $\mathrm{Cu}(\mathrm{OH})_{2}$.

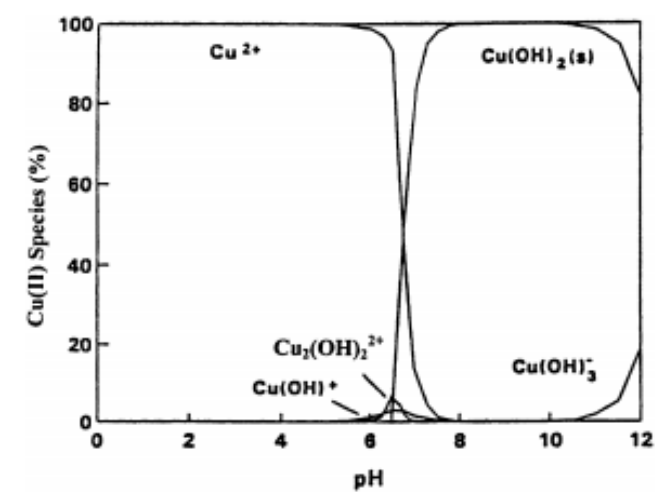

Fig. 4. Relative concentration of $\mathrm{Cu}$ (II) species in a system containing $1 * 10^{-4} \mathrm{~mol} / \mathrm{l} \mathrm{Cu}(\mathrm{II})$; from Schneider (1995).

The $\mathrm{Cu}$ (II) form is also stable within the low $\mathrm{pH}$ range, however, its concentration decreases sharply in aqueous solution with increasing $\mathrm{pH}$. Maximum adsorption at $\mathrm{pH}=5$ indicates that it is the $\mathrm{Cu}(\mathrm{II})$. Form of $\mathrm{Cu}(\mathrm{II})$, which is the predominant species between $\mathrm{pH}=1$ and 5, which is adsorbed preferentially on the PSTM-3T.

3.2. Effect of initial concentration

The removal of $\mathrm{Cu}$ (II) adsorption on PSTM-3T is shown in Fig. 3 to increase with time and attains a maximum value at about $180 \mathrm{~min}$, and thereafter, it remains almost constant. On changing the initial concentration of $\mathrm{Cu}(\mathrm{II})$ solution from 2 to $20 \mathrm{mg} / \mathrm{l}$, the amount adsorbed increases from 2.0 to $7.0 \mathrm{mg} / \mathrm{g}$ at $\mathrm{pH}=5$ using PSTM-3T with average particle size of $0.2 \mathrm{~mm}$ (Fig. 3). From Fig.3, it can be seen that the amount of

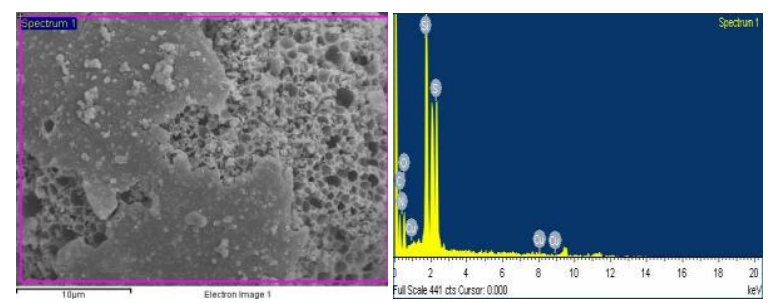

Fig.5. SEM/EDS images of PSTM-3T after adsorbed $\mathrm{Cu}(\mathrm{II})$

adsorbate with low initial concentration attained on the solid phase is smaller than the amount attained when high initial concentrations are used. However, the percentage removal of $\mathrm{Cu}$ (II) for the PSTM3T is not similar with lower initial concentrations and higher initial concentrations.

The PSTM-3T after adsorbed of $\mathrm{Cu}(\mathrm{II})$ was characterized by scanning electron microscope (SEM) and the EDS analysis (Fig. 5 ). The compositions from the peak areas are calculated as shown in Table 2.

Table 2. EDS composition of PSTM-3T after adsorbed $\mathrm{Cu}(\mathrm{II})$

\begin{tabular}{|c|c|c|}
\hline Elements & Weight, \% & Atomic, \% \\
\hline Carbon (C) & 42.81 & 58.68 \\
\hline Silica $\quad(\mathrm{Si})$ & 20.68 & 12.12 \\
\hline Oxygen $(\mathrm{O})$ & 18.45 & 18.99 \\
\hline Sulfur (S) & 16.35 & 8.40 \\
\hline Nitrogen (N) & 1.49 & 1.76 \\
\hline Copper $(\mathrm{Cu})$ & 0.21 & 0.05 \\
\hline
\end{tabular}




\section{Effect of temperature}

The adsorption of $\mathrm{Cu}(\mathrm{II})$ on the PSTM3T at different temperatures increases in the adsorption capacity when the temperature is increased. The adsorption capacity varies with temperature and initial concentration as shown in Fig.6. With increase in temperature from 298 to $363 \mathrm{~K}$, the adsorption capacity increased from 4.80 to $8.60 \mathrm{mg} / \mathrm{g}$ for the initial concentration of $10 \mathrm{mg} / \mathrm{l}$ at $\mathrm{pH} 5.0$. Similar trends are observed for all the other concentrations. This indicates that the adsorption reaction is endothermic in nature.

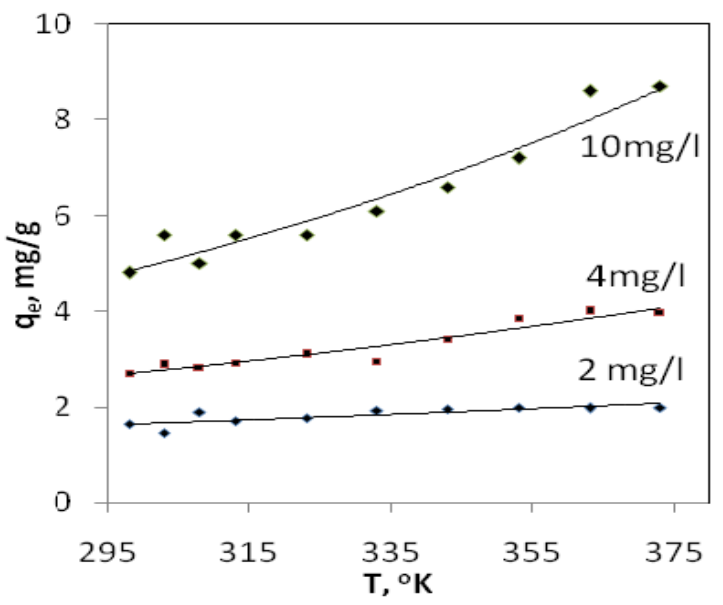

Fig.6. Effect of temperature for the different concentrations at $\mathrm{pH}=5.0$.

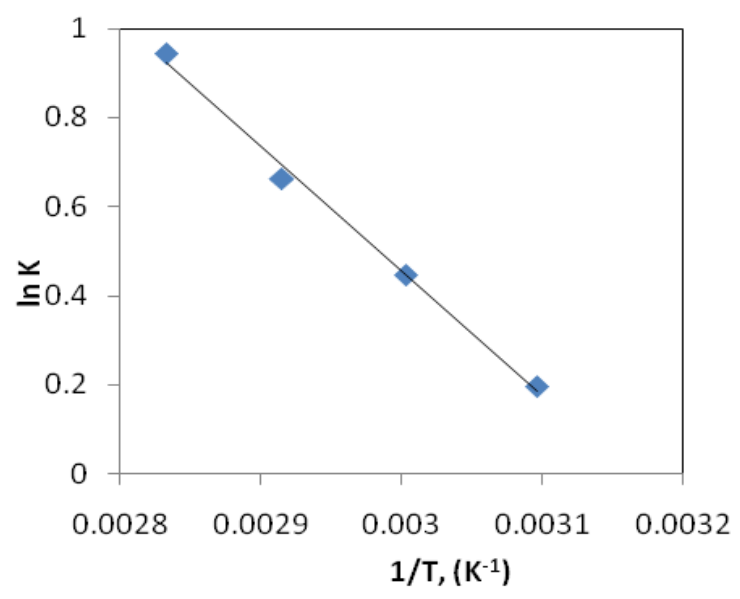

Fig.7. Vant Hoff's plot at concentration of $10 \mathrm{mg} / \mathrm{l}, \mathrm{pH} 5.0$.

The enhancement in the adsorption capacity may be due to the chemical interaction between adsorbates and adsorbent, creation of some new adsorption sites or the increased rate of intra-particle diffusion of $\mathrm{Cu}$ (II) ions into the pores of the sorbent at higher temperatures[9]. The standard Gibb's energy was evaluated by

$$
\Delta \mathrm{G}^{0}=-\mathrm{RT} \ln \mathrm{K}_{\mathrm{c}}
$$

The equilibrium constants $\mathrm{K}_{\mathrm{c}}$ was calculated at each temperature using the following relationship

$$
\mathrm{K}_{\mathrm{c}}=\mathrm{C}_{\mathrm{Ae}} / \mathrm{C}_{\mathrm{e}}
$$

where $\mathrm{C}_{\mathrm{Ae}}$ is the amount adsorbed on solid at equilibrium and $\mathrm{C}_{\mathrm{e}}$ is the equilibrium concentration.

The other thermodynamic parameters such as change in standard enthalpy $\left(\Delta \mathrm{H}^{0}\right)$ and standard entropy $\left(\Delta S^{0}\right)$ were determined using the following equations

$$
\operatorname{Ln} \mathrm{K}_{\mathrm{c}}=\Delta \mathrm{S}^{0} / \mathrm{R}-\Delta \mathrm{H}^{0} / \mathrm{RT}
$$

$\Delta H^{0}$ and $\Delta S^{0}$ were obtained from the slope and intercept of the Vant Hoff's plot of $\ln \mathrm{K}_{\mathrm{c}}$ versus 1/ $\mathrm{T}$ as shown in Fig.7. Positive value of $\Delta \mathrm{H}^{0}$ indicates that the adsorption process is endothermic. The negative values of $\Delta G^{0}$ reflect the feasibility of the process and the values become more negative with increase in temperature. Standard entropy determines the disorderliness of the adsorption at solid-liquid interface. Table 3 summarizes the results.

Table 3. Thermodynamic parameters of PSTM-3T at initial concentration of $10 \mathrm{mg} / 1, \mathrm{pH} 5.0$

\begin{tabular}{lccc}
\hline $\mathrm{T}(\mathrm{K})$ & $\Delta \mathrm{G}(\mathrm{kJ} / \mathrm{mol})$ & $\Delta \mathrm{H}(\mathrm{kJ} / \mathrm{mol})$ & $\Delta \mathrm{S}(\mathrm{J} / \mathrm{mol} \mathrm{k})$ \\
\hline 323 & -0.526 & & \\
333 & -1.237 & 28.33 & 11.64 \\
343 & -1.890 & & \\
343 & -2.770 & & \\
\hline
\end{tabular}

\section{Adsorption kinetics modeling}

The models of adsorption kinetics correlate the solute adsorption rate, thus these models are important in water treatment process design. In this study, the adsorption dynamics were followed by conducting the adsorption of $\mathrm{Cu}$ (II) on the adsorbent for a batch reaction as described before.

\section{Pseudo-first-order model}

The sorption kinetics may also be described by a pseudo-first-order according to Ho and McKay [1] and Namasivayam and Kardivelu [10]:

$$
\mathrm{dq} / \mathrm{dt}=\mathrm{k}^{\prime}\left(\mathrm{q}_{\mathrm{e}}-\mathrm{q}\right)
$$

Where $\mathrm{q}_{\mathrm{e}}$ is the amount of solute adsorbed at equilibrium per unit weight of adsorbent $(\mathrm{mg} / \mathrm{g}), \mathrm{q}$ the amount of solute adsorbed at any time $(\mathrm{mg} / \mathrm{g})$ and $\mathrm{k}^{\prime}$ is the adsorption constant. Equation (5) is integrated for the boundary conditions $t=0$ to $>0(q=0$ to $>0)$ 
and then rearranged to obtain the following linear time dependence function:

$$
\log \left(\mathrm{q}_{\mathrm{e}}-\mathrm{q}\right)=\log \left(\mathrm{q}_{\mathrm{e}}\right)-\mathrm{k}^{\prime} \mathrm{t} / 2.303
$$

Plot for equation (6) was made for PSTM-3T at different $\mathrm{pHs}$, different initial concentrations. Fig. 8 is shown as an example for these plots. Approximately, linear fits are observed for all pHs, concentrations indicating that sorption reaction can be approximated to first-order kinetics. The smallest correlation coefficient in case of $\mathrm{pH}=2$ was 0.863 , which is even better than the second-order reaction model (Figure not shown). The highest correlation coefficient was 0.995 for $\mathrm{pH}=4$ (Table 3 ).

The highest removal efficiency of PSTM-3T for $2 \mathrm{mg} / \mathrm{l}$ and $4 \mathrm{mg} / \mathrm{l}$ of $\mathrm{Cu}$ (II) was found 99.9\% and $99.5 \%$ respectability (Table 4 ). The increase in the efficiency of removal may be attributed to the fact that with an increase in the adsorbent dosage, more adsorbent surface is available for the solute to be adsorbed [11].
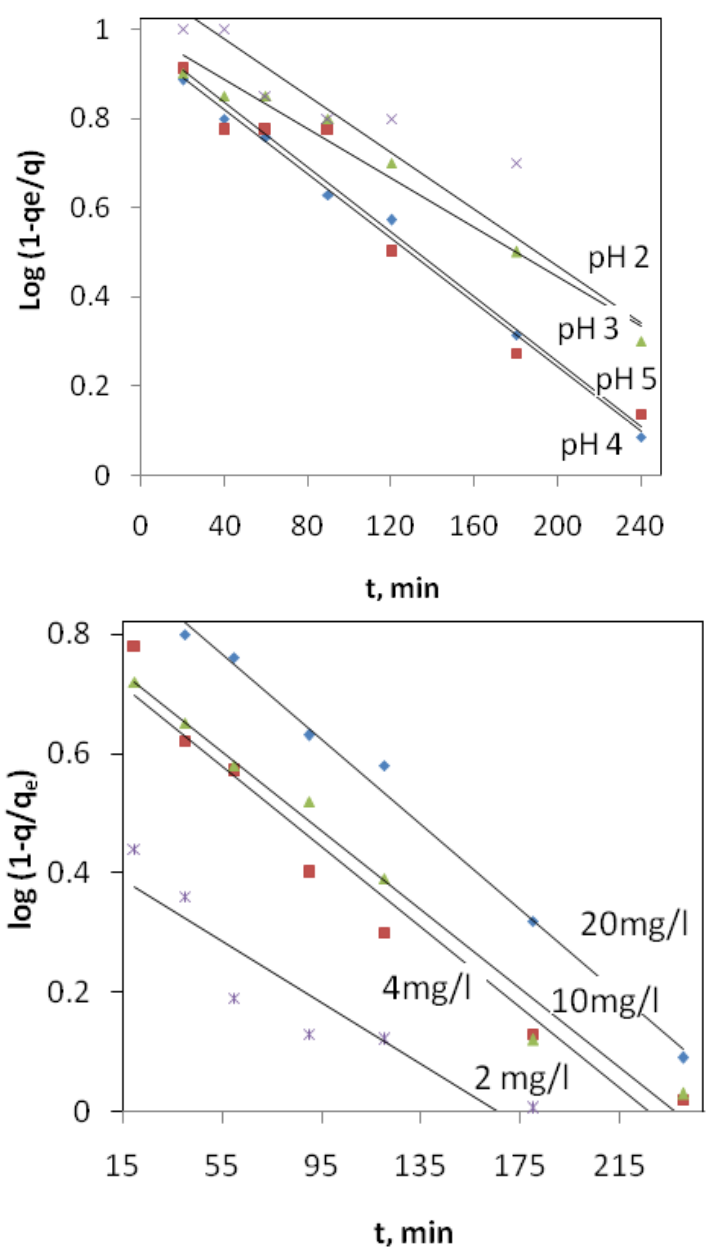

Fig.8. First-order kinetics plot for adsorption of $\mathrm{Cu}(\mathrm{II})$ on PSTM-3T at different pHs and at different initial concentrations.
Constant k' for all situations tested have been calculated and summarized in Tables 3, 4 .

Table 4. The first-order reaction rate constants for PSTM-3T at different $\mathrm{pHs}^{\mathrm{a}}$

\begin{tabular}{lcccc}
\hline Sorbent & $\mathrm{pH}$ & $\mathrm{k}^{\prime}\left(\mathrm{min}^{-1}\right)$ & $\mathrm{r}^{2}$ & $\mathrm{R} \mathrm{( \% )}$ \\
\hline PSTM-3T & 2 & 0.0050 & 0.863 & 10.0 \\
& 3 & 0.0024 & 0.971 & 20.0 \\
& 4 & 0.0030 & 0.995 & 22.0 \\
& 5 & 0.0034 & 0.953 & 35.0 \\
\hline
\end{tabular}

a Temperature $=90^{\circ} \mathrm{C}$, particle size $=0.2 \mathrm{~mm}$, initial concentration $=20 \mathrm{mgl}$.

Table 5. The first-order reaction rate constants for PSTM-3T at differentinitial concentrations ${ }^{\mathrm{a}}$

\begin{tabular}{lcccc}
\hline Sorbent & $\mathrm{C}_{0}(\mathrm{mg} / \mathrm{l})$ & $\mathrm{k}^{\prime}\left(\mathrm{min}^{-1}\right)$ & $\mathrm{r}^{2}$ & $\mathrm{R}(\%)$ \\
\hline PSTM-3T & 2 & 0.0076 & 0.862 & 99.9 \\
& 4 & 0.0036 & 0.957 & 99.5 \\
& 10 & 0.0028 & 0.982 & 87.0 \\
& 20 & 0.0032 & 0.993 & 35.0 \\
\hline
\end{tabular}

${ }^{\mathrm{a}}$ Temperature $=90^{\circ} \mathrm{C}$, particle size $=0.2 \mathrm{~mm}$, $\mathrm{pH}=5$

\section{Adsorption isotherm}

The equilibrium data for adsorption of $\mathrm{Cu}$ (II) on to the PSTM-3T may follow the rearranged Langmuir equation [11]:

$$
\mathrm{C}_{\mathrm{e}} / \mathrm{q}_{\mathrm{e}}=1 / \mathrm{Q}^{0} \mathrm{~b}+\mathrm{C}_{\mathrm{e}} / \mathrm{Q}^{0}
$$

Where $\mathrm{C}_{\mathrm{e}}$ is the equilibrium concentration (mg / l) and $\mathrm{q}_{\mathrm{e}}$ the amount adsorbed at equilibrium ( $\mathrm{mg} / \mathrm{g}$ ). The Langmuir constants $\mathrm{Q}^{0}$ and $\mathrm{b}$, which are related to the adsorption capacity and heat of adsorption, respectively, were determined (Table 5) from the slope and intercepts of the linear plots of $\mathrm{C}_{\mathrm{e}} / \mathrm{q}_{\mathrm{e}}$ versus $\mathrm{C}_{\mathrm{e}}()$.

Table 6. Langmuir and Freundlich constants for PSTM-3T at $298 \mathrm{~K}$

\begin{tabular}{l|c|cc|cc}
\hline \multirow{2}{*}{ Sorbent } & \multicolumn{3}{|c|}{ Langmuir } & \multicolumn{2}{c}{ Freundlich } \\
\cline { 2 - 6 } & $\mathrm{T}(\mathrm{K})$ & $\mathrm{Q}^{0}(\mathrm{mg} / \mathrm{g})$ & $\mathrm{b}$ & $\mathrm{K}_{\mathrm{f}}(\mathrm{mg} / \mathrm{g})$ & $\mathrm{n}$ \\
\hline PSTM-3T & 298 & 16.0 & 12.19 & 1.66 & 0.13 \\
\hline
\end{tabular}

Freundlich isotherm describes the heterogeneous surface energies by multilayer adsorption and is expressed in linear form as [11] $\ln \mathrm{q}_{\mathrm{e}}=\ln \mathrm{K}_{\mathrm{f}}+\mathrm{b}_{\mathrm{f}} \ln \mathrm{C}_{\mathrm{e}}$ where $\mathrm{K}_{\mathrm{f}}$ indicates adsorption capacity $(\mathrm{mg} /$ $\mathrm{g}$ ) and $\mathrm{b}_{\mathrm{f}}$ an empirical parameter related to the intensity of adsorption, which varies with the heterogeneity of the sorbent. For values in the range $0.1<b_{f}<1$, adsorption is favorable [11]. 


\section{Conclusion}

Synthesized

poly[N,N'-bis(3-

silseskquioxanilpropyl)thiocarbamide] is used for the removal of $\mathrm{Cu}(\mathrm{II})$ from aqueous solution. Sorption of $\mathrm{Cu}(\mathrm{II})$ is found to be effective in the low $\mathrm{pH}$ range and at higher temperatures. Increase in adsorption with rise in temperature reveals that the adsorption is chemical in nature and the process is endothermic, which is confirmed by the thermodynamic parameters evaluated. The Langmuir isotherm fits the data better than the Freundlich isotherm. Thus, the results shows that the PSTM-3T can be effectively applied for the removal of $\mathrm{Cu}$ (II) from natural water where is the content of $\mathrm{Cu}(\mathrm{II})$ lower than $10 \mathrm{mg} / \mathrm{l}$.

\section{References}

1. G. McKay, M.J. Bino, A.R. Altamemi, The adsorption of various pollutants from aqueous solutions onto activated carbon, Water Res. 19 (4), (1985) pp.491-495.

2. Ivo A.H. Schneider, Jorge Rubio, Ross W. Smith, Biosorption of metals onto plant biomass: exchange adsorption or surface precipitation, Int. J. Mineral Processing 62 (2001) pp.111-120.

3. Boronkov M. G., Vlasova N. N., Pozidaev Yu. N., Pestunovich A. E., Kirillov A. I., Visokoeffectivnii kompleksit I amfolit - poly[N,N'bis(3-

silseskquioxanilpropyl)thiocarbamide] , DAN SSSR, T.320, № 3 (1991) p.658-662.

4. Burmaa Gunchin, Sorbtsionnie svoistva kremniiorganicheskikh polymerov $\mathrm{s}$ carbofunktsionalnimi thiouriednimi gruppami po otnosheniyu $k$ zolotu i serebru, Avtoref. (1992) 18p.
5. Burmaa G., Organosilicon polymers as an effective sorbents for gold(III), Reports of the Chemistry Institute, MAS, (1995) p.1-5.

6. G. Burmaa, I. Sukhbaatar, Yu. Ganchimeg, Sorption activities and mechanism of silicon organic polymers for Noble metals (Au, Ag, $\mathrm{Pt}, \mathrm{Pd}, \mathrm{Rh}$ ), MUST, MTS, Erdem shinjilgeenii byteeliin emkhetgel, № 2/114, (2010) pp.215-221.

7. T. Azzaya, G. Burmaa, R. Egashira, Sh. Nyamdelger Comparison of the adsorption activity of chromium from tannery wastewater by Pinus activated carbon and silicon organic polymer PSTM-3T

8. Unifitsirobannie metodi analisa vod, Pod obshei redaktsiei Yu. Yu. Lurie, (1973) p. 270-273.

9. J. Chen, S. Yiacoumi, T. G. Blaydes, Equilibrium and kinetic study of copper adsorption by activated carbon, Sep. Technol. 6 (1996) p.133-146.

10. C. Namasivayam, K. Kardivelu, Uptake of mercury(II) from wastewater by activated carbon from an unwanted agricultural solid byproduct, Carbon 37 (1999) p.79-84.

11. Salim, M. and Munekage, Y. Removal of Arsenic from aqueous solution using silica ceramic: Adsorption kinetic and equilibrium studies, Int. J. of Environm. Res. Vol. 3, No 1, (2009) p.13-22. 